\title{
Ehrlich Unit
}

National Cancer Institute

\section{Source}

National Cancer Institute. Ehrlich Unit. NCI Thesaurus. Code C96599.

A unit of measure equal to one milligram of urobilinogen per deciliter. 